\title{
Pattern of Characteristics of Leachate Generation from Municipal Solid Waste Landfill by Lysimeter Experiment
}

\author{
Kasam, Sarto, Siti Syamsiah, and Agus Prasetya
}

\begin{abstract}
Management of municipal solid waste in Indonesia is majority disposed to landfill. The are some problem on landfill in Yogyakarta namely are scavenger, cattle cow and leachate generation. The characteristics of landfill leachate generation will occur dynamically depending on the various factors including: precipitation (rainfall), evapotranspiration, water content of waste, density, field capacity, waste composition, age of waste in the landfill. This research aims to identify the characteristics of leachate generation from landfills by simulation of landfill. It was conducted by two lysimeter with $2.4 \mathrm{~m}$ high and $0.7 \mathrm{~m}$ diameter. The refuse were used as samples taken from the Piyungan landfill, Bantul regency, Special Province of Yogyakarta. Characteristic of Leachate is expressed by BOD, COD, TDS parameters. The results showed that the characteristics decay of the leachate generation from landfill with recirculated faster than without recirculated. The mathematical equations of exponential form to describe the characteristics pattern of leachate with BOD, COD and TDS parameters. Peak concentration for BOD $=7118.8 \mathrm{mg} / \mathrm{L}$ and $7411 \mathrm{mg} / \mathrm{L}, \mathrm{COD}=11232 \mathrm{mg} / \mathrm{L}$ and $1184 \mathrm{mg} / \mathrm{L}, \mathrm{TDS}=3920.9$ $\mathrm{mg} / \mathrm{L}$ and $4443.1 \mathrm{mg} / \mathrm{L}$ lysimeter-1 and lysimeter-2 respectively. Validation was performed using statistical criteria of goodness of fit Chi-Square with a confidence level of 0.1 shown still meet Chi-Square standards.
\end{abstract}

Index Terms-Municipal solid waste, landfill, leachate characteristic, decay pattern.

\section{INTRODUCTION}

Disposal of municipal solid waste to landfill is the majority methode in Indonesia. The impact of landfill are gas and leachate generation which happen dynamically both quantity and quality. This dynamism is caused by various factors. [1] Identifie that there are 25 factors could cause the dynamic leachate generation and grouped into four components namely climate and geohydrology, management and operation, waste characteristics and internal processes. The leachate generation influenced by precipitation (rain water), evapotranspiration, water content of waste, density, field capacity, waste composition, age of waste, and environmental temperature [2].

The percent of rainwater into the leachate between $12.4 \%$ $27.2 \%$ depending on the thickness of the waste burial [3]. COD parameter between 30,000 to $45,000 \mathrm{mg} / \mathrm{L}$ during the rainy season and decreased drastically to $2,000 \mathrm{mg} / \mathrm{L}$ in the

Manuscript received September 5, 2015, revised November 13, 2015. Kasam is with the Islamic University of Indonesia, Yogyakarta, Indonesia (e-mail: Kasam_tl@yahoo.com)

Sarto, Siti Syamsiah, and Agus Prasetya are with the Department of Chemical Engineering, University of Gadjah Mada, Yogyakarta, Indonesia (e-mail: sarto@chemeng.ugm.ac.id, syamsiah@chemeng.ugm.ac.id, aguspras@chemeng.ugm.ac.id). dry season [4]. Studies conducted note that the evapotranspiration of $63.32 \%$ on the trash heap thickness of 3 $\mathrm{m}$ and $59.27 \%$ on land that no trash heap. Based on the measurement data in different landfills was found that the value of evapotranspiration of $764 \mathrm{~mm}$ of rain and other flow amounted to $7170 \mathrm{~mm}$ per year [5]. Through landfill lysimeter experiment diameter of $1.52 \mathrm{~m}$ and a height of $1.52 \mathrm{~m}$ was obtained that the percolation between 0.12 to $11.44 \mathrm{~cm}$ per year of $95.72 \mathrm{~cm}$ of precipitation water per year [6]. Results of a study conducted by [7] note that with the addition of leachate through the recirculation will enhance the degradation process of waste that marked concentrations of BOD and COD are more likely to trash the recirculated.

Compared meshophilic conditions and psychophilic, landfill with high ambient temperatures (thermophilic) would increase the rate of waste degradation marked the high COD concentration [8]. Constituents in the leachate change quite large between the landfill by recirculation and landfill without recirculation [9]. The quality of leachate from landfills will experience variations contained correlation with age of the waste in landfills. The maximum concentration of most of the leachate parameters such as BOD and COD occurred between year 1 and 2 and decreased gradually after more than 10 years [10]. Differences in quality that occurs quite large between young landfills and landfills that have been stable. [11] Describes the leachate BOD parameters from young landfills amounted to $2031.62 \mathrm{mg} / \mathrm{L}$, while the old landfill at 195.83 $\mathrm{mg} / \mathrm{L}$.

\section{MAteriaLS AND MethodS}

\section{A. Lysimeter Preparation and Solid Waste Sample}

Four lysimeters made of concrete were prepared in this study. Lysimeter-1 (L-1) is an experiment for a new refuse without leachate recirculation and lysimeter-2 (L-2) for a new refuse with leachate recirculation. Lysimeter-3 (L-3) and Lysimeter-4 (L-4) for mixed waste (young and old waste) without leachate recirculation to L-3 and recirculation of leachate to L-4. The heights and diameters of all lysimeters were $2.40 \mathrm{~m}$ and $0.70 \mathrm{~m}$, respectively, it is shown at Fig. 1 . The upper part consisted of a perforated pipe to add the infiltration water. The bottom part contained a gravel layer that served as the waste base and allowed the leachate to store and flow through the effluent pipe.

Sample of waste are used as research material taken from Piyungan landfill, Bantul Residence consists of four types that are based on the age, namely: a new waste or less than 1 year, 1-2 years, 2-5 years, and 5-10 years. Methode of sampling in the landfill based on zones, depth and weather around the 
landfill. Sampling of waste done at $25 \mathrm{~cm}$ in depth from the surface except for the new garbage taken on the surface and weather is no rain. Lysimeter run for 260 days continuously. Leachate characteristics are determined by the parameters Biochemical Oxygen Demand (BOD), Chemical Oxygen Demand (COD), and Total Disolved Solid (TDS).

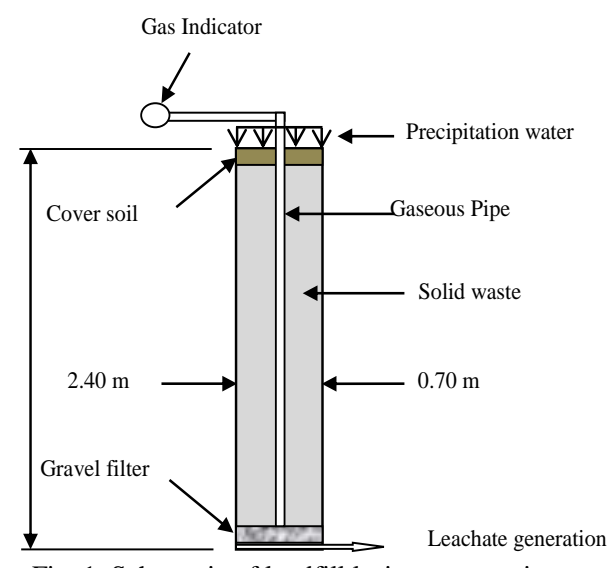

Fig. 1. Schematic of landfill lysimeter experiment

\section{B. Infiltration Water and Lecahate Characteristic Analysis}

The study was conducted at Quality Laboratory on Department of Environmental Engineering, Faculty of Civil Engineering and Planning, Islamic University of Indonesia, Yogyakarta. The precipitation water was done by rainfall simulation. In this study focused on the rainy season when high amounts of leachate are generated. In the simulation, the actual infiltration through the landfill was showed with intensity range from 20 to $50 \mathrm{~mm} / \mathrm{h}$ per day.

Analysis of experiments data conducted with the theoretical explanations, both qualitatively and quantitatively and compared with results of previous studies that are relevant. The data analysis was carried out in a comprehensive manner that the overall discussion of research topics covering all parameters associated with the dynamic generation of leachate. The quality of leachate is discribe with parameters BOD, COD, and TDS. Pattern of leachate quality is expressed by the mathematical equations of eksponsial functions as used by [12], [13] namely:

$$
C(t)=C_{0} e^{-k t}
$$

with, $C(t)=$ concentration of leachate quality parameters at the waste age of t days $(\mathrm{mg} / \mathrm{L}), C_{0}=$ maximum concentration of leachate $(\mathrm{mg} / \mathrm{L}), k=$ constant rate of decline of the leachate quality parameters (1/day) and $t=$ age of waste (day). Equation validated by methods goodness of fit Chi-Square at a significance level of 0,1 .

\section{RESULTS AND DISCUSSION}

\section{A. $B O D$}

One of the purposes of the BOD testing is for the implementation of the management of leachate as determine the size of the processing units, the measuring efficiency of processing and determine compliance with the limits (quality standards) is allowed to discharge leachate to water bodies. BOD of leachate generation based on the experimental data and the eq. (1) is shown in Fig. 2.

In general indicated that the leachate generation BOD of the four lysimeter has a similar pattern, and there are two main stages: stage one and stage two. Stage one is the initial stage ie since the garbage filled up to a maximum BOD concentration. BOD at one stage was low, between 1050-1250 mg/L and increased rapidly became 5960 - $8950 \mathrm{mg} / \mathrm{L}$ within 40-68 days. In stage two, its decreased slowly into $1160-2270 \mathrm{mg} / \mathrm{L}$ araund 200 days after the operation. The degradation pattern of the four lysimeter in line with some of the degradation patterns in other locations, as noted by [14] and [2]. Lysimeter experiment shown that the time until a maximum concentration $\left(\mathrm{T} 1_{\mathrm{L}-1}, \mathrm{~T} 1_{\mathrm{L}-2}, \mathrm{~T} 1_{\mathrm{L}-3}, \mathrm{~T} 1_{\mathrm{L}-4}\right)$ faster. Ref. [15] explains that the time at each stage to the second stage of degradation is about 80 days, until the third phase is 120 days. It is due to the rainfall and the components of organic matter in landfill Piyungan is higher.

Experiment data indicate that the maximum degradation until a stable pattern for BOD parameter can be approximated using Eq.(1) and obtained respectively $\mathrm{C}_{\max }, \mathrm{k}$ and $\mathrm{R}^{2}$, and the goodness of fit Chi-Square $\left(X^{2}\right)$ shown in Table 1 . The maximum BOD $\left(C_{\max }\right)$ of the new garbage leachate recirculation and done (L-2) is the highest, $7411.0 \mathrm{mg} / \mathrm{L}$ and the lowest $6011.9 \mathrm{mg} / \mathrm{L}(\mathrm{L}-3)$ is a mixed waste and without leachate recirculation. The value of $X^{2}$ of the all lysimeter known smaller than the value of $X_{\mathrm{o}}^{2}$. It shown that the using mathematical equations is quite valid.

TABLE I: $C_{\text {MAKS }} K, R^{2}$, AND $X^{2}$ OF LEACHATE BOD PARAMETERS
\begin{tabular}{|c|c|c|c|c|}
\hline Lysimeter & $\begin{array}{c}C_{\max } \\
(\mathrm{mg} / \mathrm{L})\end{array}$ & $k(1 /$ day $)$ & $R^{2}$ & $X^{2}$ \\
\hline L-1 & 7118,8 & $-0,0058$ & 0,8806 & 18,84 \\
\hline L-2 & 7411,0 & $-0,0071$ & 0,8604 & 17,97 \\
\hline L-3 & 6011,9 & $-0,0089$ & 0,8613 & 13,61 \\
\hline L-4 & 6489,2 & $-0,0098$ & 0,8628 & 16,22 \\
\hline
\end{tabular}

Fig. 2 also shows the effect of leachate recirculation on BOD for the different ages of waste. Based on experiment data and results of equation plotting are known that the presence of leachate recirculation effect to BOD parameter both mixed and anmixed waste. The waste age is younger resulted BOD higher than older age both leachate recirculation and without recirculation. It is caused of the high degradable organic material in young garbage. Compared with the results by [14] show that the process of degradation of waste relatively slower. Temperature, particle size and complexity and composition of waste are main factor. Operating temperature of lysimeter experiment is $29-32^{\circ} \mathrm{C}$ while the operating temperature is approximately $35^{\circ} \mathrm{C}$ [14]. The smaller particle size of the waste is also a cause of degradation faster. The high complexity and degradabel material causes degradation faster [13].

\section{B. $C O D$}

COD in leachate generation of lysimeter experiment and vitting is shown in Fig. 3. Similarly, BOD parameter, COD patterns over time also has two main stages: stage one (T1) as a increasing stage and stage two (T2) as a decreasing. T1 is 
indicated by the low COD and increased rapidly to maximum concentration. The highest COD is shown $\mathrm{T} 2_{\mathrm{L}-1}, \mathrm{~T} 2_{\mathrm{L}-2}, \mathrm{~T} 2_{\mathrm{L}-3}$, and $\mathrm{T} 2_{\mathrm{L}-4}$ respectivelly. The decay of COD is approximated using eq.(1) resulted $k, R^{2}$ and $X^{2}$ as shown in Table II. Validation counted by the standard value of Chi-Square $\left(X_{O}^{2}\right)$ of 19.77 indicating quite valid.

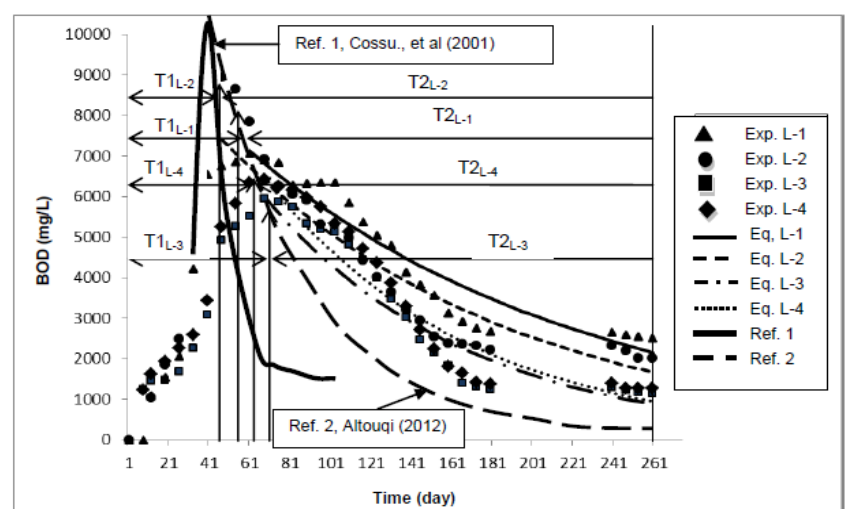

Fig. 2. Monitoring data and equation plotting of leachate BOD at lysimeter experiment.

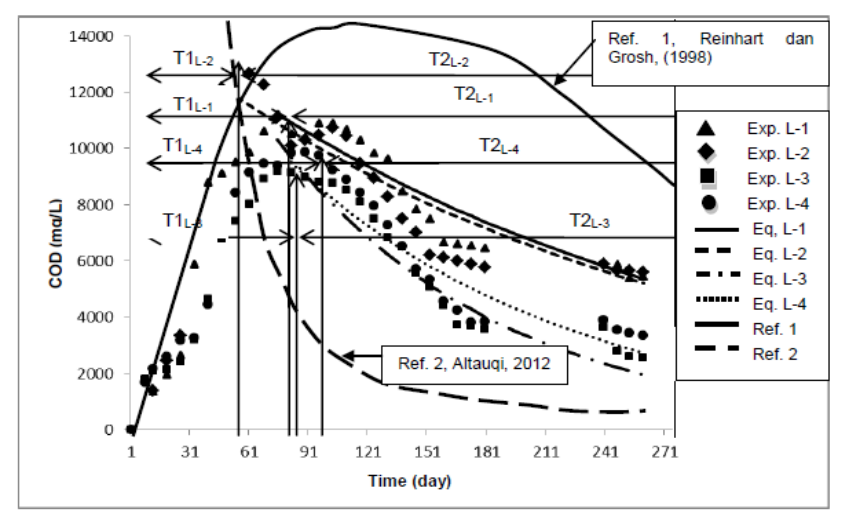

Fig. 3. Monitoring data and equation plotting of leachate COD at lysimeter experiment.

TABLE II: $C_{\text {MAK }}$ s, $K, R^{2}$ AND $X^{2}$ OF LEACHATE COD PARAMETERS
\begin{tabular}{|c|c|c|c|c|}
\hline Lysimeter & $\begin{array}{c}C_{\max } \\
(\mathrm{mg} / \mathrm{L})\end{array}$ & $k(1 /$ day $)$ & $R^{2}$ & $X^{2}$ \\
\hline L-1 & 11232 & $-0,004$ & 0,8901 & 15,83 \\
\hline L-2 & 11845 & $-0,004$ & 0,8345 & 18,94 \\
\hline L-3 & 9493 & $-0,007$ & 0,8537 & 15,23 \\
\hline L-4 & 10304 & $-0,009$ & 0,9452 & 11,87 \\
\hline
\end{tabular}

The recirculation of leachate show that are influence on the COD, especially to the maximum conditions. COD concentration after maximum conditions tend to be lower for the lysimeter were without recirculation. It is explan that the leachate recirculation will accelerate to degradation of waste in the landfill. [16] Concluse that the add of leachate and animal fecal to the waste in the landfill will accelerate the degradation process. Compared with another landfill as proposed by [2] and [15] shows that the COD leachate from all lysimeter lower and faster. It is caused by the waste capacity of lysimeter and complexity simplified. The volume of waste in the landfill the greater and simpler types of waste such as waste organic fraction majority will provide a faster degradation characterized by high COD concentration [13].

\section{TDS}

TDS in leachate consists of salt, sodium, calcium, chloride, sulfate and iron. Its concentration tended to follow the same pattern with BOD and COD that are increase rapidly in the first stage (T1) and decrease slowly in two stage (T2). The experimental data are explained that the TDS at T1 between 517 up to $5180 \mathrm{mg} / \mathrm{L}$, occurred at the 75 days and T2 between 860-1240 mg/L at the 200 days. Fig. 4 explan of TDS concentration of leachate generation may describe the stages of biodegradation of waste in landfill that are initial adjustment and transition stage, acid formation and formation of methane as proposed by [2] and [13].

Using of eq.(1) to simulate of leachate TDS obtained $\mathrm{C}_{\max }$, $k$, and $R^{2}$ is shown in Table III. Compared to research by [7], TDS in the lysimeter experimental show considerable differences, especially after passing maximum stage. It is caused higher organic waste in the lysimeter. Filling continuity of waste will cause differences TDS concentrations in the leachate. Landfill is active, the waste is additions continuity and result of fluctuations TDS [10]

TABLE III: $C_{\text {MAKS }} K, R^{2}$, AND $X^{2}$ OF LEACHATE TDS PARAMETERS
\begin{tabular}{|c|c|c|c|c|}
\hline Lysimeter & $\begin{array}{c}C_{\max } \\
(\mathrm{mg} / \mathrm{L})\end{array}$ & $k(1 /$ day $)$ & $R^{2}$ & $X^{2}$ \\
\hline L-1 & 3920,9 & $-0,008$ & 0,8314 & 17,19 \\
\hline L-2 & 4443,1 & $-0,011$ & 0,7636 & 20,07 \\
\hline L-3 & 2398,0 & $-0,008$ & 0,6701 & 22,77 \\
\hline L-4 & 3517,3 & $-0,009$ & 0,7452 & 21,28 \\
\hline
\end{tabular}

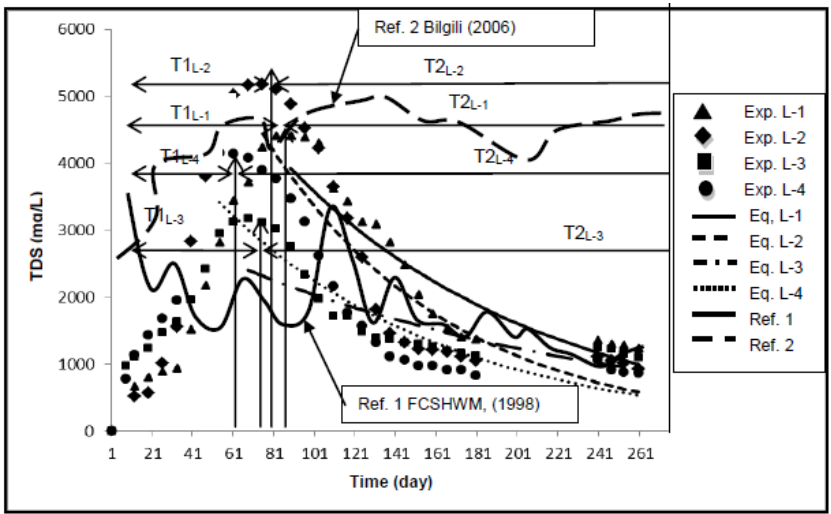

Fig. 4. Monitoring data and equation plotting Of leachate TDS at Lysimeter Experiment.

Compared with the results of research by [7], the TDS in the lysimeter leachate experimental results show considerable differences, especially after passing through $\mathrm{T} 1$ or maximum stage. This is because organic waste is significant in the experiment. Continuity of landfill waste will also cause differences TDS concentrations in the leachate. TPA which is still active, the garbage is still ongoing additions continuity and result TDS be fluctuations [10].

\section{CONCLUSIONS}

Based on the lysimeter experiments with samples of waste from Piyungan landfill, Bantul distric can be concluded: The rate of waste decomposition can be faster by smaller waste, younger age, high organic and the addition of leachate. Leachate recirculation on the waste in the landfill produce and accelerate the maximum concentration of BOD, COD and TDS at leachate generation. Leachate generation from the 
landfill increase along with increasing of waste age in the landfill. Equations of exponential function can be used to describe a leachate generation quality pattern in every time.

\section{ACKNOWLEDGMENTS}

The authors thank to The Quality Laboratory of Environmental Engineering Department, Faculty of Civil Engineering and Planning, Islamic University of Indonesia for the contribution and work to this research. This research would not have happened without their help.

\section{REFERENCES}

[1] M. El-Fadel and E. Bou-Zeid, "Long term simulations of leachate generation and transport from solid waste disposal at a former quarry site," Journal of Solid Waste Technology and Management, vol. 28, no. 2, May 2002.

[2] G. Tchobanoglous, H. Theisen, and S. A. Vigil, Integrated Solid Waste Management, Engineering Principles and Management Issues, McGraw-Hill, New York, 2004.

[3] I. K. Baucon and C. H. Ruhl, "CCP leachate generation and leachate management," presented at World of Coal Ash Conference, Lexsington, K.Y, April 2013.

[4] J. Trankler, D. R. Manandhar, Q. Xiaoning, V. Sivapornpun, and W. Schöll, "Effects of monsooning conditions on the management of landfill leachate in tropical countries," in Proc. Sardinia, Eighth International Waste Management and Landfill Symposium, Pula, Cagliari, Italy, vol II, pp. 59-68, 2011.

[5] V. L. Hauser and D. M. Gimon, "Evaluating evapotranspiration (ET) landfill cover performance using hydrologic Models," Air Force Center for Environmental Excellence, January 2004.

[6] K. D. Barnswell and D. F. Dwyer, "Assessing the performance of evapotranspiration covers for municipal solid waste landfills in Northwestern Ohio," Journal of Environmental Engineering, ASCE, April 2011.

[7] M. S. Bilgili, A. Demir, and B. Ozkaya, "Quality and quantity of leachate in aerobic pilot-scale landfills," Environmental Management, vol. 38, no. 2, pp. 189-196, 2008.

[8] Y. Wang and M. Pelkonen, "Impacts of temperature and liquid/solid ratio on anaerobic degradation of municipal solid waste: An Emission investigation of landfill simulation reaktors," Jounal of Mater Cycles Waste Manage, vol. 11, pp. 312-320, 2009.
[9] J. Scott, R. Beydoun, R. Amal, G. Low, and J. Cattle, "Landfill management, leachate generation, and leach testing of solid wastes in Australia and overseas," Critical Reviews in Environmental Science and Technology, vol. 35, no. 3, p. 239, 2005.

[10] Florida Center for Solid and Hazardous Waste Management (FCSHWM), "Analysis of Florida MSW landfill leachate quality," University of Central Florida, Florida, 1998.

[11] A. H. Lee, H. Nikraz, and Y. T. Hung, "Influence of waste age on landfill leachate quality," International Journal of Environmental Science and Development, vol. 1, no. 4, October 2010.

[12] R. K. Rowe, "Leachate characteristics for MSW landfill," Geotechnical Research Centre, Dept. of Civil Engineering, University of Western Ontario, London, Ontario, Canada N6A 5B9, 1995.

[13] Altauqi, "Modeling leachate BOD And COD using lab-scale reactor landfills and multiple linear regression analysis," Dissertation of Doctor of Philosophy The University of Texas At Arlington, December 2012.

[14] R. Cossu, R. Raga, and D. Rossetti, "Proceedings sardinia 2001, Eighth international waste management and landfill," presented at Symposium S. Margherita di Pula, Cagliari, Italy, October 1-5, 2001.

[15] D. R. Reinhart and C. J. Grosh, "Analysis of Florida MSW landfill leachate quality," Florida Center for Solid and Hazardous Management, Gainesville, FL, 1998

[16] C. Rout and A. Sharma, "Municipal solid waste stabilisation by leachate recirculation: A case study of Ambala city, international," Journal of Environmental Sciences, vol. 1, no. 4, 2010.

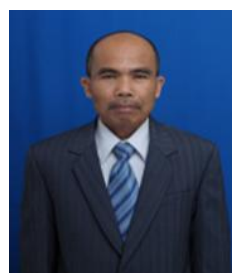

Kasam was born in Cilacap, Indonesia on August 7 , 1966. He studied civil engineering from the Department of Civil Engineering, Islamic University of Indonesia, Yogyakarta, Indonesia, 1991, and the post graduate study in environmental engineering from the Department of Enviromental Engineering, Technology Institute of Bandung, Indonesia, 1998, and the Ph.D program from the Department of Chemical Engineering, University of Gadjah Mada, Yogyakarta, Indonesia, 2015. He worked as an associate professor in the Department of Environmental Engineering, Islamic University of Indonesia, Yogyakarta Indonesia. His main research fields are in solid waste management.

He worked as a team leader on design engiheering detail of municipal solid waste landfill in West Nusa Tenggara Province, Indonesia, 2011 and planning of intermediate treatment facility of municipal solid waste at Ministry of Public Works, Jakarta, Indonesia, 2012. He published several articles. 